\title{
Multimodality and Multiliteracies: The Case of Language Socialization in Urban Family in Surabaya
}

\author{
Layli Hamida, Universitas Airlangga
}

\begin{abstract}
This study examined the way language socialization fostered literacy development. It aims at exploring and illustrating how the richness of multimodal and multilingual communicative practices has been part of parent-child interaction at home in Jagir community in Surabaya. Twenty one first grade elementary school students reside in urban area were observed during learning activities at home for a period of 12 months. Audio and video recorded of parent-child verbal interactions were transcribed and analyzed and children writing portofolio were assessed. Based on micro level analysis of parent-child interaction the studies examine the pattern of socialization. The result of the research shows that to teach their children, parents use several strategies which are multimodal in nature leading to children development of multiliteracies. It has been suggested that multimodal text making with parents (which includes the use of voice, image, and gesture) as well as the use of technological facilities help children cope with school literacy practices. Not only are students skillful in reading and writing task, but they also develop critical thinking which is very important for their ability of solving school assignment. The findings point on the implications of language socialization by discerning at the interaction between caregiver and child, rather than just one side of the conversation as conceived hitherto by most of language socialization studies.
\end{abstract}

Keywords: caregiver-child interaction; language socialization; multimodality; multiliteracies

\section{Introduction}

First grade is a stage of transition from playful preschool situation to a more formal and serious academic nuance. In this stage, children face multi task demanding a higher level of literacy. Aside from basic literacy skill like reading and writing, in first grade, students need to be able to narrate, to provide response for the teacher question and instruction, to take turn in conversation, to follow instruction independently, to collaborate in task assignment, and to think critically. Children need multiliteracies to survive the learning requirement.

Children need a supporting learning environment that could afford for an assisting bridge between pre and school situation. Learning with parents at home is considered to benefit children in gaining knowledge and competence to be able to cope with the demand. Parents and other family members socialize children to their surrounding since birth. The first and foremost socialization conducted is language socialization which in Ochs and Shieffelin concept is the socialization through language and socialization to use language (Ochs \& Schieffelin, 1986: 163). By means of language socialization, children learn about words, environment, how to express themselves, how to follow instruction, including how to read and write. Sterponi. (2012: 227) stated that "the paradigm of language socialization posits that learning to read and write implies not only the acquisition of a set of cognitive and motor skills but also a cultural apprenticeship into community's values, social positions, and identities which are associated with locally shaped literacy practices." It means that in literacy socialization at home children were socialized to acquire multi-literacy and to become a competent member of society. In the case of first grade students, literacy socialization at home prepare them to become a qualified member of the school institution.

This study examined the way language socialization fostered literacy development. It aims at exploring and illustrating how the richness of multimodal and multilingual communicative 
practices has been part of parent-child interaction at home. Researches on parents' role in children literacy development have been abundant (Heath, 1983; Neuman, 2000). Some of the researches portray young children's multimodal and multilingual practices (Scribner \& Cole, 1981) or characterize the fashion in which language was embedded in a broader communicational setting (Kress, 1997). The present study consents with the recognition of multimodality in parents' language socialization strategies as well as the implications of the socialization on children development of competence. In other words, unlike most study of language socialization which more often than not focusing only on caregivers' speech (Jacknick, 2008), it attempts at examining both side of the conversation. It argues that multimodality employs by parents in learning situation with children at home could play a significant role in enhancing their literacy skills needed at school.

\section{Method}

Twenty one parents and their 7 to 8 years old children were recruited from one of elementary schools in a culturally urban of Surabaya. The participants came from a range of low to middle class families. The parents from the low economic group mostly graduated from elementary school. Some of the parents from low middle class and middle class group are graduated from high school. Only two parents are university graduate. All of the participants are bilinguals speaking both Javanese and Indonesian. Some of the children spoke Javanese as their first language and some of them speak Indonesian. A mixed between Javanese and Indonesian was the language of instruction during parents-child interaction.

Parents and children were audio and video reported while engaged in learning situation at home. The time for recording is on the average of 0.30 minutes to $57: 48$ minutes. The total recording was 880 minutes 55 seconds or equals to 14 hours 67 minutes. The result of the recording was transcribed autographically. Depth interview was conducted with parents to obtain a more elaborate understanding of the social historical track of children's' literacy acquisition.

Data transcription of parents-child interaction was analyzed using micro level analysis of language. Any additional source of modes such as gestures and images were described. The result of micro level analysis is utilized to examine the pattern of language socialization and strategy used by parents.

\section{Result}

The results of the analysis show that interaction between parents or caregiver and child is naturally multimodal. However, the number and type of the interaction as well as the multimodality employed varied from family to family. For example, though all families utilize the same book for the purpose of guiding their children learning outside school, not all of them take the lesson and exercise from the book devotedly. Parents and caregivers from low and low-middle families use the book only to take out some ideas to do dictation. It happens because most children in the low and low-middle class family still struggle in reading and writing. Therefore, the parents decided to give more practices on them to spell. Another reason is that the parents claimed that those are the only ways they know on how to guide their children to learn. They do not know how to use the book and the exercises contained in it.

The book used for the learning exercise at home is a thematic book. It is specifically provided for the implementation of 2013 curriculum by the Indonesian government. The book is integrated as all basic subjects like Indonesian, Science, and Mathematics are presented in a storyline manner. It is divided into eight episodes to finish in two semesters. It contains a lot of pictures on it and it provides an exercise designed specifically for student and parents to practice and discuss at home. 
As parents and caregivers from low to low-middle class family are mostly elementary graduates, it is probably difficult for them to follow parents guidance in the book without any training. The exercises for parents and children demand a discussion and collaboration of thinking which is beyond their capacities. Moreover, they are not accustomed to the integration of several subjects into one theme. In their old days, subjects are taught independently from each other and that is what they can teach their children.

On the other hand, parents and caregiver from middle class family and three other from low and low-middle class family approached the book differently. They read the instruction of the exercise for their children, they modeled the reading material, they explained difficult terms. During the interaction, they also make discourse expansion in the form of narration or explanation and they even use different modes in their explanation.

From social semiotic perspective multimodality means that language is fundamentally social and cultural. It is dynamic and able to be modified by users rather than being a static code (Jewitt, 2006). Mills (2016) states that multimodal literacy describes communication practices that use two or more modes of meaning. While modes are the socially and culturally shaped resources or organized semiotic structures for making meaning such as written language, speech, gesture, movement, music, images, etc. (Mills \& Unsworth, 2016).

Some of parents multimodal use of language and technological facilities observed in this study are as follows:

1. The use of thematic book

As explained earlier, first grade elementary students in Surabaya (and Indonesia) use thematic book for learning at school. This book is also used for parents and caregivers to guide children learning at home. During the process of learning, children and parents often encounter difficult words or new concepts. In dealing with those situation, parents employ several modes to provide explanation and elaboration for the children. They give model of reading for the children and also ask them to read to understand the material. They employ deictic term and point on the picture, using physical context in the book, to show children the meaning of certain terms.

2. Learning from television

Most parents except 1 from low economic family have television at home. From 20 parents, 17 of them claimed that they also use $T V$ programs as media for interaction with their children and learn from them. Their children watch children programs such a cartoon series entitle "Upin \& Ipin" and an encyclopedic program for children namely "Laptop Si Unyil." The existence of television and the program chosen play a great deal in developing children multi-literacy. The multimodality involved in tv shows provide a huge opportunity for children to enhance their background knowledge which is important for their later success in reading and writing. The story of "Upin \& Ipin" for example, presents a decontextualized text of narration. By watching the story, children were carried into a past or future situation. Children were offered with illustration of things and situation which is not here and now. This kind of narration enhances children cognition and develops their vocabularies. They also learn about sequence organization from each episode. In addition, pictures that come along with the story could trigger the growth of their imagination.

3. The use of gadget

One of the challenges of the $21^{\text {st }}$ century is the rampant use of gadget and internet. Most children participants in this study even the ones from low economic class own a tablet or mobile phone. If they do not have one for themselves, they usually are allowed to use their parents' mobile phones. However, not all children make use of the gadget for learning purposes. Only two of them have the habit to browse on YouTube to search for informative video such videos about the origin of human or cooking recipes. Most others use their tablet 
for playing games or browse for race car videos. No matter what kind of information they search or type of use the gadget for, the employment of that technological facilities develop children' digital literacy. Of course, control and attention from parents will become the determinant on how children would hold value from it

Children surely benefit from multimodality employed by their parents during learning situation. First, written language, and physical context for new words explanation may enhance their vocabularies which is then important for the acquisition of reading fluency as it can increase children word recognition. Second, the employment of television program for parent-child interaction could develop their narrative ability written or oral. Finally, the use of gadget and internet as non-educative as it is, may build on children digital literacy.

\section{Conclusion}

Parents-child interaction in learning situation at home contains rich resources for children development of multiliteracies. The multimodality used by parents during the interaction add on resources available for children for the advantage of their learning. Family learning is not the only or most powerful learning. Parents' language socialization is probably only one of the many factors for children acquisition of literacy. However, children will develop a higher level of engagement in creative fluency-building activities when they have opportunities to explore any educative information in conversation with more expert partners.

\section{References}

Heath, S. B. 1983. Ways with words: language, life, and work in communities and classrooms. Cambridge: Cambridge University Press.

Jacknick, C. M. 2008. Language socialization in the tub: eExamining both sides of the interaction. Working Papers in TESOL and Applied Linguistics. vol 8, no. 2.

Jewitt, C. 2006. Technology, literacy, and learning: A multimodal approach. Abingdon, UK: Routledge.

Kress, G. 1997. Before writing: rethinking the path to literacy. London: Routledge.

Mills, K. A. 2016. Literacy theories for the digital age: social, critical, multimodal, spatial, material, and sencory lenses. UK: Multilingual Matters.

Mills, K. A. \& Len Unsworth. 2016. Multimodal Literacy. In Oxford Research Encyclopedia of Education. Oxford University Press, USA.

Neuman, S. 2000. Social contexts for literacy development: A family literacy program. In Roskos, $\mathrm{K}$ \& Christie, J (eds.). Play and Literacy in early childhood: Research from multiple perspective. New Jersey: Erlbaum, pp. 153-168.

Ochs, E. \& Schieffelin, B. B .1986. Language socialization. Annual Review of Anthropology, 1. Annual Review Inc.

Scribner, S. \& Cole, M. 1981. The psychology of literacy. Cambridge: Harvard Universty Press.

Sterponi, L. 2012. Literacy socialization. In Duranti,. Alessandro,. Ochs, E., Bambi, B., \& Schieffelin (eds.). The handbook of language socialization. U. K: Blackwell Publishing Limited. 